\title{
GLP-1 Receptor Expression in Human Tumors and Human Normal Tissues: Potential for In Vivo Targeting
}

\author{
Meike Körner, Martin Stöckli, Beatrice Waser, and Jean Claude Reubi \\ Division of Cell Biology and Experimental Cancer Research, Institute of Pathology, University of Bern, Bern, Switzerland
}

\begin{abstract}
Peptide hormone receptors overexpressed in human tumors, such as somatostatin receptors, can be used for in vivo targeting for diagnostic and therapeutic purposes. A novel promising candidate in this field is the GLP-1 receptor, which was recently shown to be massively overexpressed in gut and lung neuroendocrine tumors - in particular, in insulinomas. Anticipating a major development of GLP-1 receptor targeting in nuclear medicine, our aim was to evaluate in vitro the GLP-1 receptor expression in a large variety of other tumors and to compare it with that in nonneoplastic tissues. Methods: The GLP-1 receptor protein expression was qualitatively and quantitatively investigated in a broad spectrum of human tumors $(n=419)$ and nonneoplastic human tissues $(n=209)$ with receptor autoradiography using 125/-GLP-1(7-36)amide. Pharmacologic competition experiments were performed to provide proof of specificity of the procedure. Results: GLP-1 receptors were expressed in various endocrine tumors, with particularly high amounts in pheochromocytomas, as well as in brain tumors and embryonic tumors but not in carcinomas or lymphomas. In nonneoplastic tissues, GLP-1 receptors were present in generally low amounts in specific tissue compartments of several organs-namely, pancreas, intestine, lung, kidney, breast, and brain; no receptors were identified in lymph nodes, spleen, liver, or the adrenal gland. The rank order of potencies for receptor binding-namely, GLP-1(736)amide = exendin-4 $\gg$ GLP-2 = glucagon(1-29)—provided proof of specific GLP-1 receptor identification. Conclusion: The GLP-1 receptors may represent a novel molecular target for in vivo scintigraphy and targeted radiotherapy for a variety of GLP-1 receptor-expressing tumors. For GLP-1 receptor scintigraphy, a low-background signal can be expected, on the basis of the low receptor expression in the normal tissues surrounding tumors.
\end{abstract}

Key Words: GLP-1 receptor; autoradiography; human tumors; pheochromocytoma; normal tissue

J Nucl Med 2007; 48:736-743

DOI: 10.2967/jnumed.106.038679

\footnotetext{
Received Dec. 6, 2006; revision accepted Feb. 15, 2007.

For correspondence or reprints contact: Jean Claude Reubi, MD, Division of Cell Biology and Experimental Cancer Research, Institute of Pathology, University of Bern, Murtenstrasse 31, P.O. Box 62, CH-3010 Bern, Switzerland.

E-mail: reubi@pathology.unibe.ch

COPYRIGHT @ 2007 by the Society of Nuclear Medicine, Inc.
}

$\mathbf{G}$ protein-coupled peptide hormone receptors play an increasing role in cancer medicine. This role is based primarily on the peptide receptor overexpression on tumor cells, which allows specific receptor-targeted scintigraphic tumor imaging and tumor therapy with radiolabeled peptide analogs (1). The somatostatin receptors were the first peptide receptors identified for these purposes, and somatostatin receptor targeting has now become an integral part of the routine management of patients with gastroenteropancreatic neuroendocrine tumors. Somatostatin receptor scintigraphy (OctreoScan [ ${ }^{111}$ In-pentetreotide]; Mallinckrodt, Inc.) detects these tumors with extremely high sensitivity and specificity (2). Moreover, recent results from clinical studies performing somatostatin receptor radionuclide therapy of these tumors are very promising $(3,4)$.

Prompted by the success of somatostatin receptor targeting, we have evaluated the overexpression of other peptide receptor families in tumors in vitro (1), with the aim, eventually, of being able to target in vivo a larger spectrum of tumors or individual tumors more efficiently with multiple peptide analogs directed against different peptide receptors expressed in the same tumor $(5,6)$. To estimate the suitability of a peptide receptor for in vivo tumor targeting, one needs detailed in vitro data on its expression in human tumors and human normal tissues. One critical prerequisite for successful in vivo targeting is a high receptor expression in tumors, allowing a high tumoral radiotracer accumulation $(4,7)$. Equally important is a low receptor expression in normal tissues surrounding tumors, at sites of tumor origin and of metastasis, for receptor-targeted scintigraphy will detect tumors with adequate sensitivity only in the case of a high ratio of tumor to background signal $(8,9)$. Moreover, knowledge of the distribution and putative functions of a peptide receptor in normal tissues is important to estimate the potential of side effects of a peptide therapy (10).

A new promising candidate for in vivo tumor targeting is the GLP-1 receptor, a member of the glucagon receptor family (11). The GLP-1 receptor was recently shown to be highly overexpressed in human gut and lung neuroendocrine tumors-particularly, in insulinomas (5). Indeed, no 
other peptide receptor has been found in such high density in insulinomas like the GLP-1 receptor. Moreover, the proof of principle for in vivo GLP-1 receptor targeting has already been provided in several rodent models: Insulinomas were successfully visualized scintigraphically after injection of radiolabeled GLP-1 analogs in rats and mice $(12,13)$; furthermore, a preliminary study has shown a dramatic reduction in tumor size after single injections of high doses of the GLP-1 analog ${ }^{111}$ In-exendin-4 in the Rip1Tag2 mouse model of insulinoma (A. Wicki, D. Wild, D. Storch, et al., unpublished data, 2007). These data predict an imminent application of these types of experiments in humans.

Up to now, however, very little is known about GLP-1 receptor expression in human tumors other than gut and lung neuroendocrine tumors; existing data are limited mainly to rodent tumor cell lines (14-18). Furthermore, current knowledge of the GLP-1 receptor expression in normal human tissues is very incomplete as well. It is based largely on receptor messenger RNA (mRNA) investigations in wholeorgan preparations (19-21), but very little information is available on the receptor protein expression, the exact tissue localization of the receptor, and the receptor density levels in human organs. Therefore, we performed a study to assess the GLP-1 receptor protein expression, first, in a broad spectrum of human tumors, and, second, in normal human tissues from common sites of tumor origin and metastasis using in vitro receptor autoradiography. This method has several advantages over other techniques: It identifies receptor binding sites that represent the in vivo target structures, it allows assessing the binding affinity of the receptor, and it permits correlation with morphology and quantification of the data (1).

\section{MATERIALS AND METHODS}

\section{Tissues}

Fresh frozen samples of tumors and normal tissues were obtained from surgical resection specimens. Four hundred nineteen endocrine, nervous, epithelial, and lymphatic tumors were investigated (Table 1). Furthermore, a large spectrum of nonneoplastic human tissues that were usually resected together with a tumor was assessed (Table 2). Finally, selected normal rodent tissues were investigated —namely, rat lung $(n=3)$, mouse lung $(n=6)$, rat thyroid gland $(n=12)$, and mouse thyroid gland $(n=5)$.

The study conformed to the ethical guidelines of the Institute of Pathology, University of Bern, and was reviewed by the Institutional Review Board.

\section{In Vitro GLP-1 Receptor Autoradiography}

The in vitro GLP-1 receptor autoradiography was performed as described previously (5). Twenty-micrometer-thick frozen tissue sections were incubated for $2 \mathrm{~h}$ at room temperature in the incubation solution containing $170 \mathrm{mM}$ Tris- $\mathrm{HCl}$ buffer ( $\mathrm{pH} 8.2), 1 \%$ bovine serum albumin (BSA), $40 \mu \mathrm{g} / \mathrm{mL}$ bacitracin, $10 \mathrm{mM} \mathrm{MgCl} 2$, and 15,000 cpm/100 $\mu \mathrm{L}{ }^{125} \mathrm{I}-\mathrm{GLP}-1(7-36)$ amide $(74 \mathrm{TBq} / \mathrm{mmol}$ [2,000 Ci/mmol]; Anawa). Nonspecific binding was determined by incubating tissue sections in the incubation solution containing, additionally, $100 \mathrm{nM}$ unlabeled (cold) GLP-1(7-36)amide (Bachem),
TABLE 1

GLP-1 Receptor Incidence and Density in Human Tumors

\begin{tabular}{|c|c|c|}
\hline Tumor type & $\begin{array}{c}\text { GLP-1 } \\
\text { receptor } \\
\text { incidence* }\end{array}$ & $\begin{array}{l}\text { GLP-1 } \\
\text { receptor } \\
\text { density }{ }^{\dagger}\end{array}$ \\
\hline \multicolumn{3}{|l|}{ Endocrine tumors } \\
\hline Pheochromocytomas & $12 / 20(60)$ & $3,970 \pm 1,002$ \\
\hline Paragangliomas & $5 / 18(28)$ & $1,353 \pm 601$ \\
\hline Medullary thyroid carcinomas & $5 / 18(28)$ & $1,326 \pm 264$ \\
\hline Adrenal cortical adenomas & $0 / 7(0)$ & \\
\hline Parathyroid carcinomas & 0/4 (0) & \\
\hline Pituitary adenomas & $0 / 38(0)$ & \\
\hline \multicolumn{3}{|l|}{ Tumors of nervous system } \\
\hline Meningiomas & $7 / 20(35)$ & $989 \pm 271$ \\
\hline Astrocytomas & $4 / 16(25)$ & $1,069 \pm 398$ \\
\hline Glioblastomas & $2 / 21(9)$ & $790 \pm 120$ \\
\hline Ependymomas & $1 / 6(16)$ & 1,075 \\
\hline Schwannomas & $0 / 9(0)$ & \\
\hline \multicolumn{3}{|l|}{ Embryonic tumors } \\
\hline Medulloblastomas & $3 / 12(25)$ & $1,246 \pm 726$ \\
\hline Nephroblastomas & $2 / 9(22)$ & $421 \pm 21$ \\
\hline Neuroblastomas & $3 / 16(18)$ & $932 \pm 518$ \\
\hline \multicolumn{3}{|l|}{ Carcinomas } \\
\hline Ovarian adenocarcinomas & 2/12 (16) & $688 \pm 384$ \\
\hline Prostate carcinomas & $1 / 20(5)$ & 1,283 \\
\hline Breast carcinomas & $0 / 22(0)$ & \\
\hline Colorectal adenocarcinomas & $0 / 21(0)$ & \\
\hline Gastric adenocarcinomas & $0 / 20(0)$ & \\
\hline Pancreatic adenocarcinomas & $0 / 21(0)$ & \\
\hline Cholangiocellular carcinomas & $0 / 17(0)$ & \\
\hline Hepatocellular carciomas & $0 / 16(0)$ & \\
\hline $\begin{array}{l}\text { Non-small cell lung } \\
\text { carcinomas }\end{array}$ & $0 / 20(0)$ & \\
\hline Small cell lung carcinomas & $0 / 6(0)$ & \\
\hline Renal cell carcinomas & $0 / 20(0)$ & \\
\hline Non-Hodgkin's lymphomas & 0/10 (0) & \\
\hline $\begin{array}{l}{ }^{*} \text { Values in parentheses are perce } \\
{ }^{\top} \text { Mean } \pm \text { SEM of receptor-positiv }\end{array}$ & ntages. & $\mathrm{m} / \mathrm{mg}$ tissue). \\
\hline
\end{tabular}

which at this concentration completely and specifically displaces ${ }^{125}$ I-GLP-1(7-36)amide at the receptors. Further pharmacologic displacement experiments were performed to differentiate GLP-1 receptors from other members of the glucagon receptor family. For this purpose, serial tissue sections were incubated with ${ }^{125}$ I-GLP-1(7-36)amide together with increasing concentrations of one of the following analogs: the GLP-1 receptor-selective analog GLP-1(7-36)amide or exendin-4 (Bachem) (22), the GLP-2 receptor-selective analog GLP-2 (Bachem), or the glucagon receptor-selective analog glucagon(1-29) (Bachem). After incubation, the slides were washed 5 times in ice-cold Tris- $\mathrm{HCl}$ buffer (170 mM; pH 8.2) containing $0.25 \%$ BSA and twice in ice-cold Tris- $\mathrm{HCl}$ buffer without BSA. The slides were dried for $15 \mathrm{~min}$ under a stream of cold air and then exposed to Kodak Biomax MR films for $7 \mathrm{~d}$ at $4^{\circ} \mathrm{C}$. The signals on the films were analyzed in correlation with morphology using corresponding hematoxylinand eosin-stained tissue slides. The receptor density was quantitatively assessed using tissue standards for iodinated compounds (Amersham) and a computer-assisted image processing system (Analysis Imaging System; Interfocus). As a positive control, a human insulinoma was used in each procedure (5). 
TABLE 2

GLP-1 Receptor Density in Receptor-Positive Human Normal Tissues

\begin{tabular}{|c|c|c|}
\hline Organ & $\begin{array}{c}\text { Tissue } \\
\text { compartment }\end{array}$ & $\begin{array}{l}\text { GLP-1 receptor } \\
\text { density* }^{*}\end{array}$ \\
\hline \multirow{2}{*}{$\begin{array}{l}\text { Central nervous } \\
\text { system }\end{array}$} & Neurohypophysis & $5,207 \pm 472 \quad(n=6)$ \\
\hline & Leptomeninges & $1,453 \pm 276 \quad(n=6)$ \\
\hline \multirow{2}{*}{$\begin{array}{l}\text { Normal } \\
\text { pancreas }\end{array}$} & Islets & $1,322 \pm 143$ \\
\hline & Acini & $693 \pm 49$ \\
\hline \multirow{2}{*}{$\begin{array}{l}\text { Chronic } \\
\text { pancreatitis }\end{array}$} & Islets & $960 \pm 251 \quad(n=6)$ \\
\hline & Acini & $567 \pm 112 \quad(n=6)$ \\
\hline Duodenum & Brunner's glands & $2,752 \pm 522 \quad(n=5)$ \\
\hline Ileum & Myenteric plexus & $887 \pm 285 \quad(n=6)$ \\
\hline Colon & Myenteric plexus & $788 \pm 84$ \\
\hline Breast & Ducts and lobuli & $519 \pm 136 \quad(n=3)$ \\
\hline Lung & Small blood vessels & $636 \pm 164$ \\
\hline Kidney & $\begin{array}{l}\text { Large- and medium- } \\
\text { sized arteries }\end{array}$ & $674 \pm 127$ \\
\hline
\end{tabular}

${ }^{*}$ Mean \pm SEM of receptor-positive cases (dpm/mg tissue).

\section{RESULTS}

\section{GLP-1 Receptor Expression in Human Tumors}

The GLP-1 receptor expression was assessed in a broad spectrum of common human tumors. Table 1 summarizes the GLP-1 receptor incidences and densities in these tumors. It shows that GLP-1 receptor expression was found mainly in endocrine, nervous, and embryonic tumors. Of these tumors, pheochromocytomas are especially noteworthy because they showed by far the highest GLP-1 receptor expression in terms of both receptor incidence and density. A representative example is shown in Figure 1; observe the high GLP-1 receptor density in this case. Also paragangliomas, medullary thyroid carcinomas, meningiomas, astrocytomas, and medulloblastomas exhibited a notable, but lower, GLP-1 receptor expression compared with pheochromocytomas. Low levels of GLP-1 receptors were identified in glioblastomas, ependymomas, neuroblastomas, and nephroblastomas (Table 1). No GLP-1 receptors were detected in adrenal cortical tumors, parathyroid carcinomas, pituitary adenomas, or schwannomas.

Conversely, among the epithelial cancers, GLP-1 receptors were found only in single cases-namely, 1 prostate and 2 ovarian adenocarcinomas (Table 1). However, GLP-1 receptors were not detected in the vast majority of ovarian and prostate carcinomas or in the other tested carcinomas, including breast carcinomas, gastrocolic adenocarcinomas, pancreatic ductal carcinomas, cholangiocellular carcinomas, hepatocellular carcinomas, non-small cell and small cell lung carcinomas, and renal cell carcinomas. Furthermore, all investigated Non-Hodgkin's lymphomas were receptor negative (Table 1 ).

\section{GLP-1 Receptor Expression in Nonneoplastic Human Tissues}

GLP-1 receptors were also investigated in a wide variety of nonneoplastic human tissues. They were found in specific organs and there in specific tissue compartments, which are summarized in Table 2. The most striking receptor expression was observed in the neurohypophysis, where indeed the highest GLP-1 receptor density of all normal tissues was measured. Also the leptomeninges directly overlying the brain surface often displayed a high receptor expression. In contrast, other brain tissues adjacent to brain tumors were rarely found to be receptor positive; however, brain regions could not be evaluated systematically for GLP-1 receptors in the material obtained in the context of brain tumor surgery. In the pancreas, both islets and acini expressed GLP-1 receptors, with higher receptor levels in the islets (Fig. 2). Of note, in chronic pancreatitis, islets were less frequently found to be receptor positive and expressed receptors in lower density compared with those in the normal pancreas (Table 2), whereas the acinar GLP-1 receptor expression appeared to be unchanged. In the duodenum, the Brunner's glands showed a high GLP-1 receptor expression (Figs. 3A and 3B).

Small amounts of GLP-1 receptors were found in the small and large intestine, breast, thyroid gland, kidney, and lung. In the ileum and colon, GLP-1 receptors were localized in the myenteric nerve plexus, whereas the submucosal nerve plexus, the muscularis, and the mucosa were receptor negative (Figs. 3C and 3D). In the breast, weak receptor expression was sometimes seen in small milk ducts and lobuli. Of 18 tested thyroid gland specimens, only a single case was GLP-1 receptor positive.

Blood vessels expressed GLP-1 receptors in specific organs. In the kidney, GLP-1 receptors were present in
FIGURE 1. Representative in vitro receptor autoradiography to assess ${ }^{125} \mid$-GLP-1 (7-36)amide binding to human tumor tissue. (A) Hematoxylin- and eosin-stained (HE) tissue section shows pheochromocytoma. Bar $=1 \mathrm{~mm}$. (B) Autoradiogram shows total binding of 125 -GLP-1(7-36)amide. There is very strong labeling of the entire tumor tissue. Inset shows autoradiogram with nonspecific (ns) binding of ${ }^{125}$ |-GLP-1 (7-36)amide: complete displacement of 125-GLP-1(7-36)amide in presence of 100 nM unlabeled (cold) GLP-1(7-36)amide.

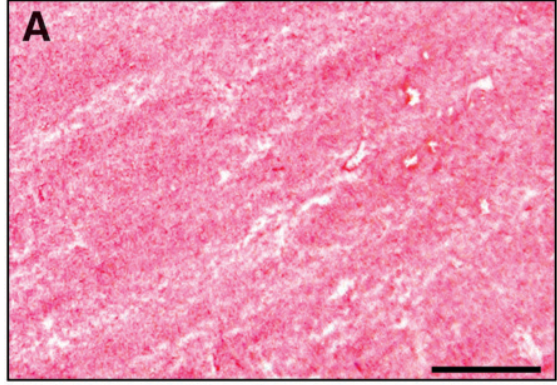

HE

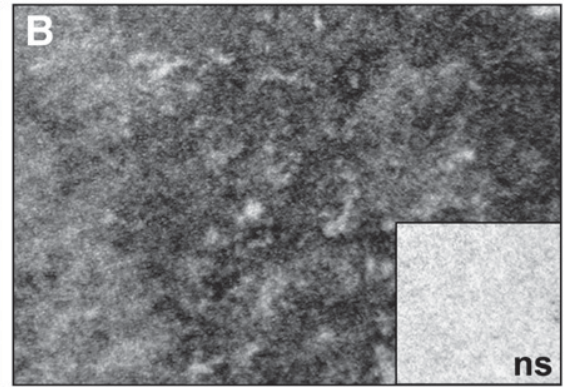

Total 

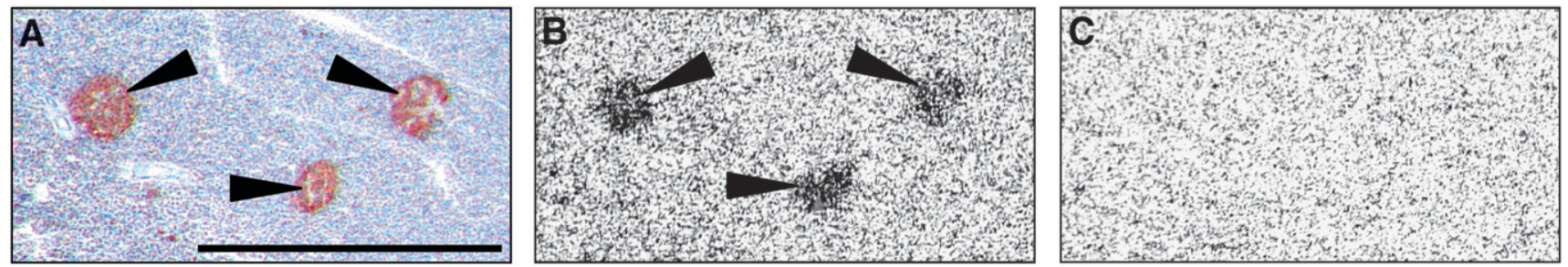

FIGURE 2. In vitro receptor autoradiography on human pancreas. (A) Immunohistochemistry for synaptophysin staining islets (arrowheads) surrounded by acini. Bar $=1 \mathrm{~mm}$. (B) Autoradiogram shows total binding of ${ }^{125}$ I-GLP-1(7-36)amide: strong binding to islets, weak binding to acini. (C) Autoradiogram shows nonspecific binding of ${ }^{125}$ I-GLP-1(7-36)amide in presence of 100 nM unlabeled (cold) GLP-1(7-36)amide.

hilar and intralobular arteries, whereas no receptors could be discerned in arterioles, veins, glomeruli, or tubuli. In the lung, GLP-1 receptors were identified in small muscular blood vessels within the alveolar septa and, more rarely, in larger blood vessels (Table 2; Figs. 4C and 4D). In the gastrointestinal tract, blood vessels were usually receptor negative except for a single stomach case with GLP-1 receptors in submucosal blood vessels.

No GLP-1 receptors were found in the following tissues: liver, spleen, lymph nodes, thymus, adrenal gland, adenohypophysis, prostate, heart, skeletal muscle, and fat.

\section{Species Differences in GLP-1 Receptor Expression Between Humans and Rodents}

For control purposes, we assessed selected rat and mouse tissues for GLP-1 receptors. We noted a very high GLP-1 receptor expression in the rodent lung and thyroid gland, which was strikingly higher in incidence and density compared with that in the same organs in humans. This is summarized in Table 3 and illustrated in Figure 4. In the lungs of rats and mice, GLP-1 binding was present in the alveolar septa where it could not be attributed to a specific anatomic structure because of the extremely strong signal (Figs. 4A and 4B). Large pulmonary blood vessels and large airways were receptor negative. In comparison, the human lung expressed significantly smaller amounts of GLP-1 receptor (Figs. 4C and 4D). Here, the receptors could be attributed in part to small blood vessels but not to the alveolar epithelium; airways were receptor negative.

The rodent thyroid gland also showed high GLP-1 receptor expression, particularly in rats. Conversely, in humans only 1 of 18 thyroid glands was receptor positive. The receptors could not be assigned with certainty to either the follicular epithelium or the medullary C-cells in rodents or in humans.

\section{Pharmacologic Characterization of GLP-1 Receptors}

GLP-1(7-36)amide is bound not only by GLP-1 receptors with high affinity but also by other members of the glucagon receptor family, such as GLP-2 and glucagon receptors, with low affinity $(23,24)$. To prove that the radioligand ${ }^{125}$ I-GLP-1(7-36)amide was specifically bound by GLP-1 receptors in the autoradiography experiments,
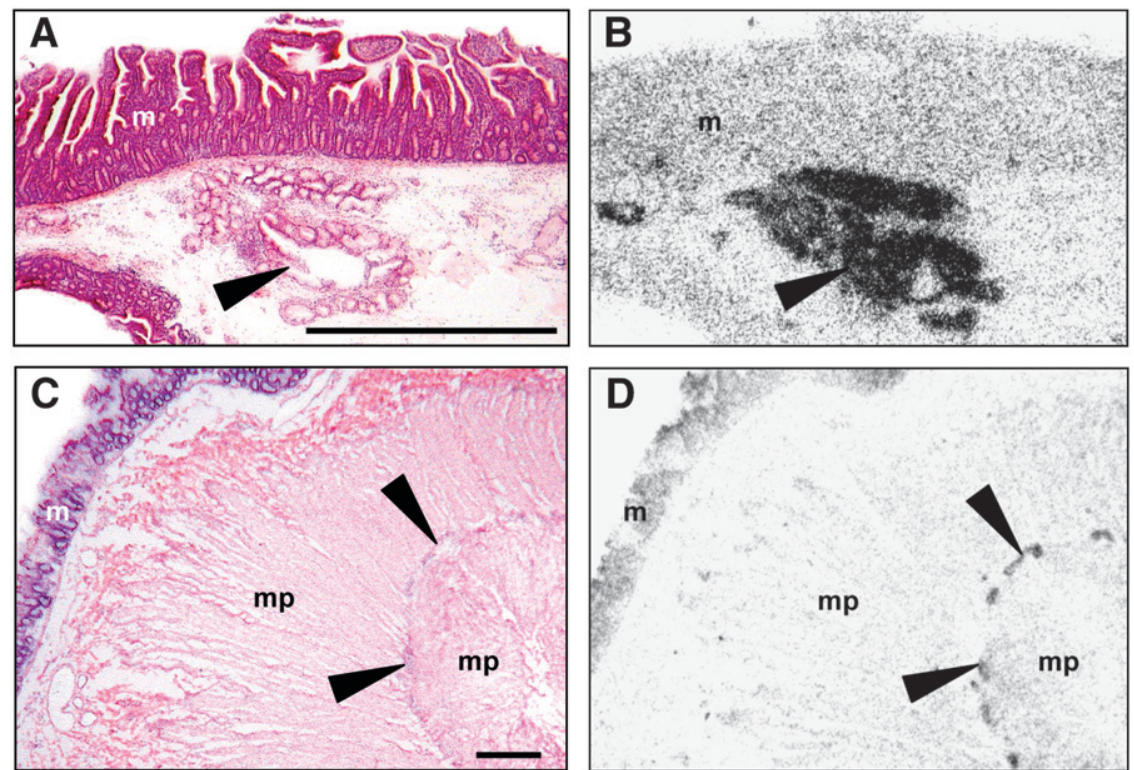

HE

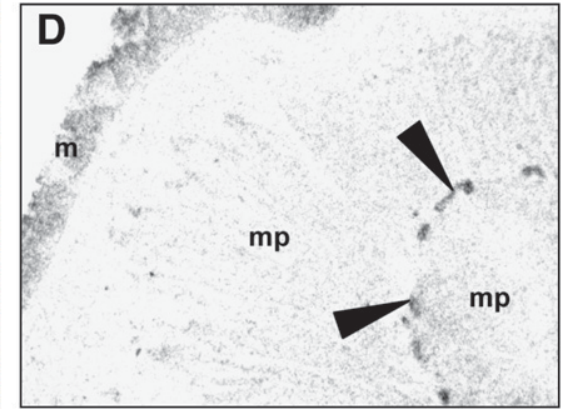

Total
FIGURE 3. In vitro receptor autoradiography on human normal tissues. (A and C) Hematoxylin- and eosin-stained (HE) tissue sections show the following: (A) duodenum with Brunner's glands (arrowhead) and overlying mucosa $(\mathrm{m})$ and $(\mathrm{C})$ colon with myenteric nerve plexus (arrowheads), muscularis propria (mp), and mucosa $(\mathrm{m})$. Bars $=1 \mathrm{~mm}$. (B and $\mathrm{D})$ Autoradiograms show total binding of 125I-GLP-1(7-36)amide. (B) Duodenum with very strong specific binding to Brunner's glands (arrowhead). Note that labeling observed in mucosa $(\mathrm{m})$ is nonspecific. (D) Colon with specific binding to myenteric plexus (arrowheads). As in the duodenum, labeling observed in mucosa $(\mathrm{m})$ is nonspecific. 
FIGURE 4. Comparison of in vitro GLP-1 receptor autoradiography of lung in rat and human. (A and $\mathrm{C}$ ) Hemotoxylin- and eosin-stained (HE) tissue sections show the following: (A) rat lung with alveolar septa (stars) and large blood vessels (arrows) and (C) human lung with alveolar septa (stars) and small blood vessels (arrows). Bars $=1 \mathrm{~mm}$. (B and D) Autoradiograms show total binding of 125 GLP-1(7-36)amide. (B) Rat lung with very strong and diffuse binding to alveolar septa (stars) and no binding to large blood vessels (arrows). (D) Human lung with topically restricted binding, partly to small blood vessels (arrows) but not to alveolar septa (stars). Complete displacement of ${ }^{125}$ I-GLP-1(7-36)amide by $100 \mathrm{nM}$ unlabeled (cold) GLP-1(7-36)amide provides proof of specific GLP-1 receptor binding (not shown).
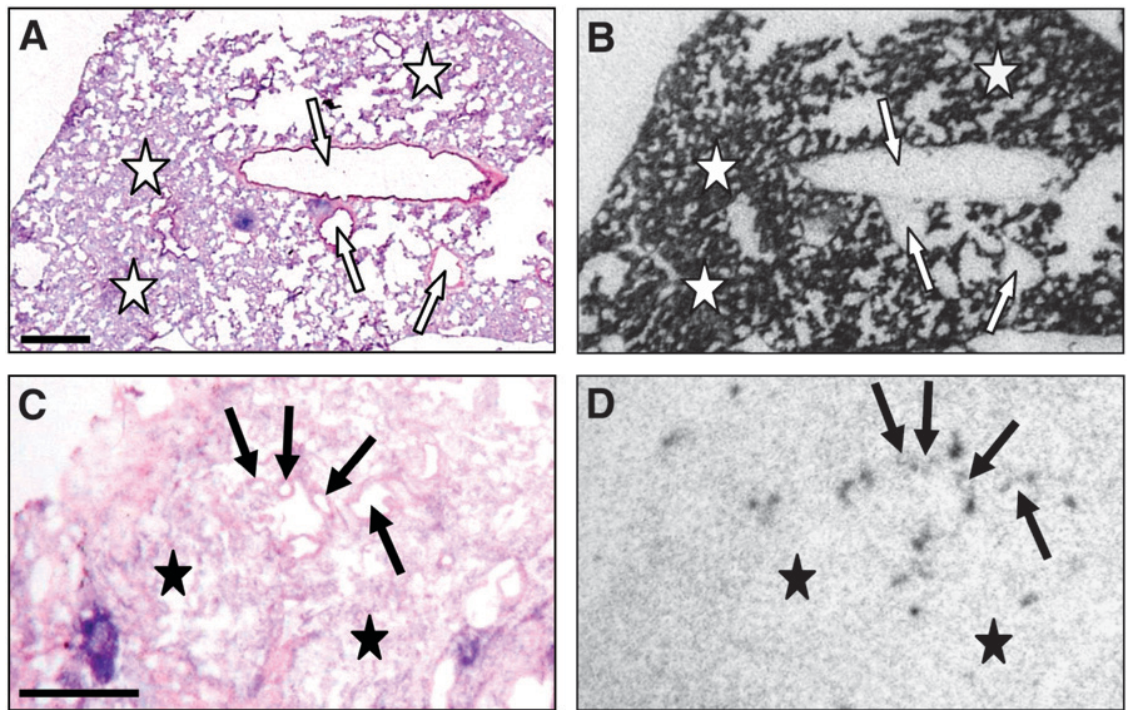

HE

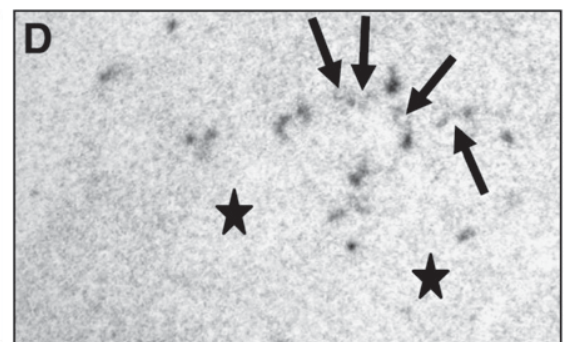

Total pharmacologic displacement experiments were performed using ${ }^{125}$ I-GLP-1(7-36)amide in competition with increasing concentrations of unlabeled (cold) GLP-1(7-36)amide, the GLP-1 receptor-selective agonist exendin-4, the GLP-2 receptor-selective agonist GLP-2, or the glucagon receptorselective agonist glucagon(1-29). Representative results for the tumors and normal tissues are shown in Figure 5. In all examples, ${ }^{125} \mathrm{I}-\mathrm{GLP}-1(7-36)$ amide is displaced by GLP-1 (7-36)amide and exendin-4 with high affinity in the nanomolar concentration range, whereas it is displaced by GLP-2 and glucagon(1-29) with low affinity in the micromolar concentration range. This rank order of potencies provides strong pharmacologic evidence that GLP-1 receptors are specifically identified $(11,25)$.

\section{DISCUSSION}

This study reports the GLP-1 receptor protein expression in a large spectrum of human tumors and normal human organs. Thus, the findings represent a significant extension of current knowledge on the tumor and physiologic GLP-1 receptor expression in humans. The study shows that GLP-1

TABLE 3

GLP-1 Receptor (GLP-1 R) Expression in Lung and Thyroid Gland of Rat, Mouse, and Human: Comparison of Receptor Incidence and Density

\begin{tabular}{|c|c|c|c|c|}
\hline Organ & GLP-1 R & Rat $^{*}$ & Mouse* & Human* \\
\hline \multirow[t]{2}{*}{ Lung } & Incidence & $3 / 3(100)$ & 6/6 (100) & $11 / 28$ (39) \\
\hline & Density ${ }^{\dagger}$ & $3,477 \pm 1,539$ & $1,677 \pm 439$ & $636 \pm 164$ \\
\hline \multirow{2}{*}{$\begin{array}{r}\text { Thyroid } \\
\text { gland }\end{array}$} & Incidence & $12 / 12(100)$ & $3 / 5(60)$ & 1/18 (6) \\
\hline & Density ${ }^{\dagger}$ & $2,289 \pm 282$ & $1,982 \pm 470$ & 1,193 \\
\hline
\end{tabular}

*Values in parentheses are percentages.

${ }^{\dagger}$ Mean \pm SEM of receptor-positive cases (dpm/mg tissue). receptors are expressed in specific endocrine, neural, and embryonic tumors, whereas they are virtually absent in carcinomas and lymphomas. Moreover, the study demonstrates that the physiologic GLP-1 receptor expression is generally low in humans, with only few tissues showing high amounts of receptor-namely, the neurohypophysis, duodenum, and pancreas. Finally, important species differences in the GLP-1 receptor expression between humans and rodents are revealed: The lung and thyroid gland exhibit a strong GLP-1 receptor expression in rats and mice but only low receptor levels in humans. Proof of a specific identification of GLP-1 receptors with autoradiography was provided by the rank order of potencies for receptor binding obtained with pharmacologic competition experiments-namely, GLP-1(7-36)amide = exendin-4 $\gg$ GLP-2 = glucagon(1-29) $(11,25)$.

The highest GLP-1 receptor expression is present in endocrine tumors. Most noteworthy among these tumors are neuroendocrine tumors of the gut and lung - in particular, insulinomas and gastrinomas (5), and pheochromocytomasbecause of their very high receptor incidence and density. Furthermore, glial brain tumors, meningiomas, and embryonic tumors also express GLP-1 receptors but generally to a lower degree than endocrine tumors. Human carcinomas were found to express virtually no GLP-1 receptors. On the contrary, recent studies have provided evidence of functional GLP-1 receptors in several human pancreatic adenocarcinoma cell lines $(18,26)$. Because we were unable to detect GLP-1 receptors in $>20$ human pancreatic carcinomas, GLP-1 receptor expression in these tumors may be restricted to cell lines and may not be relevant in humans in vivo.

The GLP-1 receptor-expressing tumors are prospective candidates for in vivo targeting for imaging and therapy analogous to the somatostatin receptor targeting. Indeed, GLP-1 receptor scintigraphy of insulinomas was shown to 

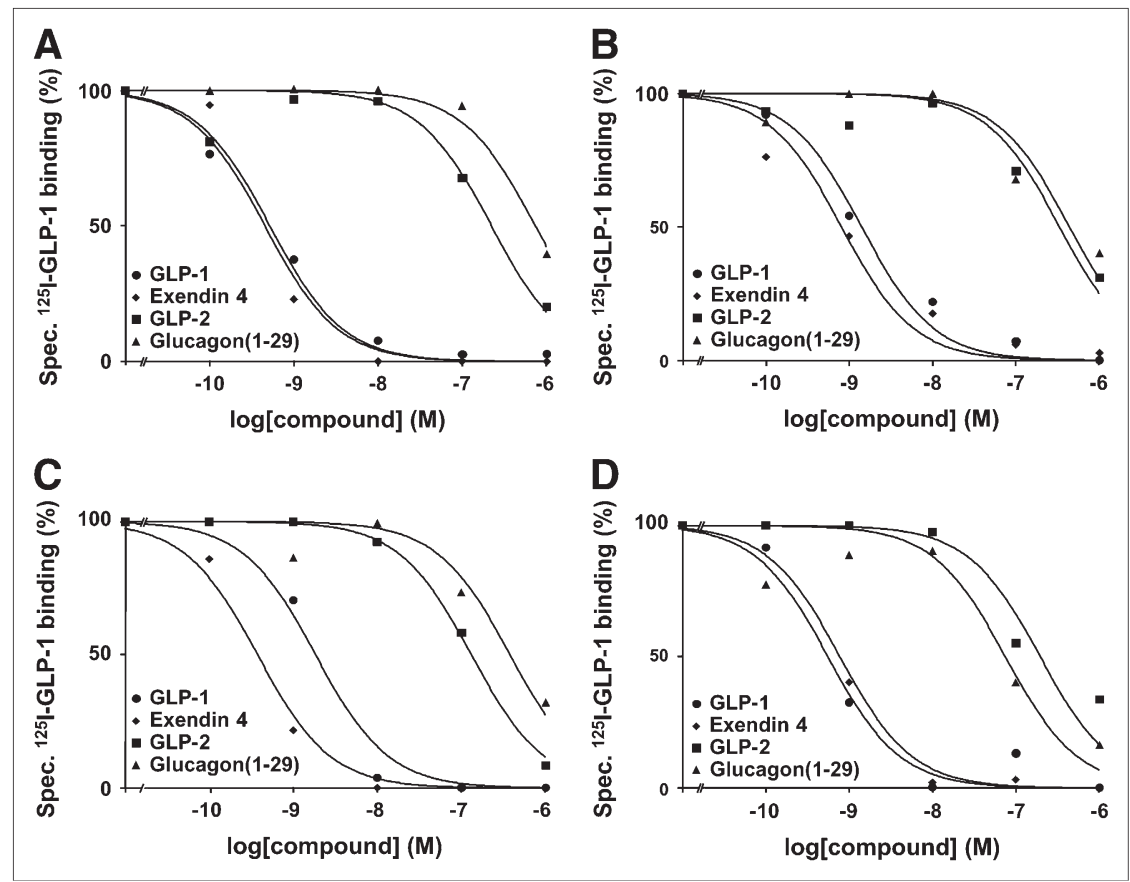

FIGURE 5. Representative competition experiments in human tumor and normal tissues - namely, pheochromocytoma (A), pancreatic islets (B), duodenal Brunner's glands (C), and myenteric nerve plexus of colon (D). In all examples, high-affinity displacement of ${ }^{125}$ I-GLP-1(7-36)amide by GLP-1 receptor-selective agonists GLP-1(7-36)amide and exendin-4 and low-affinity displacement by GLP-2 receptor-selective agonist GLP-2 and glucagon receptor-selective agonist glucagon(1-29) was evident. be highly effective in several animal models: Insulinomas transplanted into the legs of rats (12) as well as insulinomas in the pancreas of Rip1Tag2 tumor mice (13) were both specifically visualized with radiolabeled GLP-1 analogs. In analogy, in humans, GLP-1 receptor-targeted tumor scintigraphy is highly promising for detection of smallest insulinomas, not visualized with ${ }^{111}$ In-pentetreotide, because of the highest GLP-1 receptor incidence and density in these tumors. Moreover, these tumors are candidates for GLP-1 receptor-targeted tumor therapy. Preliminary data have shown impressive results using the ${ }^{111}$ In-labeled, stable GLP-1 analog exendin-4 to completely destroy mice insulinomas (A. Wicki, D. Wild, D. Storch, et al., unpublished data, 2007). Not only tumors with high GLP-1 receptor expression, such as insulinomas and pheochromocytomas, but also tumors with lower receptor levels could be assigned to in vivo GLP-1 receptor targeting-namely, to multireceptor targeting-as they often coexpress other peptide receptors, such as somatostatin receptors, cholecystokinin 2 receptors, or substance $\mathrm{P}$ receptors $(1,5)$. For in vivo GLP-1 receptor targeting of tumors, stable GLP-1 analogs are required, as naturally occurring GLP-1 receptor agonists are rapidly degraded in the blood $(25,27,28)$. Such GLP-1 analogsthat is, ${ }^{123} \mathrm{I}-\mathrm{GLP}-1(7-36)$ amide, ${ }^{123} \mathrm{I}$-exendin-3, and [Lys ${ }^{40}$ (Ahx-[ ${ }^{111}$ In-DTPA])]exendin-4 - are presently being developed $(12,13)$.

Tumor GLP-1 receptors may be important not only because they can internalize radiotracers into tumor cells (13) but also because they possibly mediate important tumor cell functions that could eventually be used for tumor therapy. At present, information on biologic GLP-1 effects on GLP-1 receptor-expressing tumor cells is available mainly from tumor cell lines. Recent data provide evidence that GLP-1 may play a role in the endocrine activity, growth, and differentiation of tumor cells. For instance, GLP-1 stimulated insulin secretion in human and rat insulinoma cell lines (29) and calcitonin secretion in a rat medullary thyroid carcinoma cell line (16,30). Furthermore, GLP-1 stimulated proliferation and inhibited apoptosis of insulinoma cells $(29,31,32)$. These growth-promoting effects of GLP-1 may be restricted to specific tumor cell types or particular experimental conditions, as they could not be reproduced in rat pheochromocytoma cells (17) or in human pancreatic adenocarcinoma cells (18). Finally, GLP-1 was shown to induce neural differentiation of rat pheochromocytoma cells (17) and endocrine differentiation of human pancreatic adenocarcinoma cells (26). GLP-1 receptor activation in human endocrine, neural, and embryonic tumors may have similar effects on tumor hormone secretion, proliferation, and differentiation in vivo. However, the biologic significance of tumor GLP-1 receptors in humans is at present largely unknown.

For evaluation of the suitability of a receptor for in vivo targeting, it is important to know the receptor expression not only in tumors but also in normal tissues. A low receptor expression in nonneoplastic tissues surrounding tumors is an essential prerequisite for sensitive and specific tumor detection with receptor-targeted scintigraphy as a high ratio of tumor to background signal can be expected. We screened normal human tissues for their GLP-1 receptor expression. Our results add important new information to the available data that are based mainly on mRNA investigations $(19,20,33)$. In the organs known to express GLP-1 receptor mRNA, we identified the receptor protein and 
could attribute it to specific tissue compartments, such as islets and acini in the pancreas and blood vessels in the lung and kidney. Furthermore, we identified other tissues that physiologically express GLP-1 receptors-including duodenal Brunner's glands, the myenteric plexus of the gut, and breast parenchyma-and we quantified the receptor density in these tissues. An important conclusion from these investigations is that the physiologic GLP-1 receptor expression is generally low in humans. The receptors are usually present in specific tissue compartments that constitute only a small portion of the whole organ; in these tissue compartments, the receptor density is usually low; and many organs are receptor negative. Thus, common sites of GLP-1 receptor-expressing primaries (such as the gastrointestinal tract) as well as sites of metastases (such as lymph nodes, liver, and lung) show only a low receptor expression or none, which is a favorable circumstance for GLP-1 receptor tumor imaging.

The characterization of GLP-1 receptors in normal tissues also represents an important basis for the investigation of physiologic GLP-1 functions in humans, which is important with regard to future long-term therapies of metabolic disorders with GLP-1 analogs and potential side effects of such therapies (27). Alhough the role of GLP-1 in pancreatic islets and brain has been intensively investigated (25), data on GLP-1 functions in other GLP-1 receptor-expressing organs is more limited. The present information on the localization of GLP-1 receptors in these organs allows speculations on GLP-1 functions in humans. For instance, GLP-1 may inhibit intestinal motility by activation of GLP-1 receptors in the myenteric plexus $(34,35)$. In the lung, GLP-1 may modulate vascular resistance at the level of small arteries (36). In the kidney, the GLP-1-mediated reduction of the glomerular filtration rate may be due to a preglomerular regulation of renal perfusion (37). In pancreatic acini, GLP-1 may regulate enzyme secretion (38). Finally, the downregulation of GLP-1 receptors in islets in chronic pancreatitis suggests that the impaired glucose tolerance in these patients may be due not only to a loss of islets but also to a reduced responsiveness of $\beta$-cells to GLP-1 (39). No data are presently available on possible GLP-1 effects in duodenal Brunner's glands or in the breast. It can only be hypothesized that GLP-1 may affect secretion or cell proliferation in these organs, in analogy to its role in other secretory organs (25).

The species differences between humans and rodents in GLP-1 receptor expression are noteworthy. The lung and thyroid gland show remarkably higher levels of GLP-1 receptor in rodents. Therefore, biodistribution data for GLP-1 analogs obtained in rodents cannot be extrapolated to humans. In particular, a lower radiotracer accumulation can be expected in the lung of humans compared with the lung of mice (13). Thus, though rodents may not be suitable models for GLP-1 receptor-targeted imaging of neuroendocrine lung tumors and medullary thyroid carcinomas, these tumors may well be visualized in humans.

\section{CONCLUSION}

GLP-1 receptors are very promising candidates for in vivo targeting for diagnostic and therapeutic purposes, on the basis of their high expression in specific tumors and their low expression in normal tissues.

\section{ACKNOWLEDGMENTS}

The authors thank Professor Helmut Mäcke for fruitful discussions. This study was supported by grant OCS01778-08-2005 from the Swiss Cancer League.

\section{REFERENCES}

1. Reubi JC. Peptide receptors as molecular targets for cancer diagnosis and therapy. Endocr Rev. 2003;24:389-427.

2. Gibril F, Reynolds JC, Doppman JL, et al. Somatostatin receptor scintigraphy: its sensitivity compared with that of other imaging methods in detecting primary and metastatic gastrinomas. Ann Intern Med. 1996;125:26-34.

3. Waldherr C, Pless M, Maecke HR, et al. Tumor response and clinical benefit in neuroendocrine tumors after $7.4 \mathrm{GBq}{ }^{90}$ Y-DOTATOC. J Nucl Med. 2002;43: 610-616.

4. Kwekkeboom DJ, Teunissen JJ, Bakker WH, et al. Radiolabeled somatostatin analog $\left[{ }^{177} \mathrm{Lu}-\mathrm{DOTA}^{0}, \mathrm{Tyr}^{3}\right]$ octreotate in patients with endocrine gastroenteropancreatic tumors. J Clin Oncol. 2005;23:2754-2762.

5. Reubi JC, Waser B. Concomitant expression of several peptide receptors in neuroendocrine tumours: molecular basis for in vivo multireceptor tumour targeting. Eur J Nucl Med Mol Imaging. 2003;30:781-793.

6. Reubi JC, Körner M, Waser B, Mazzucchelli L, Guillou L. High expression of peptide receptors as a novel target in gastrointestinal stromal tumours. Eur J Nucl Med Mol Imaging. 2004;31:803-810.

7. Krenning EP, Valkema R, Kwekkeboom DJ, et al. Molecular imaging as in vivo molecular pathology for gastroenteropancreatic neuroendocrine tumors: implications for follow-up after therapy. J Nucl Med. 2005;46(suppl 1): $76 \mathrm{~S}-82 \mathrm{~S}$.

8. van der Harst E, de Herder WW, Bruining HA, et al. [ $\left.{ }^{123} \mathrm{I}\right]$ Metaiodobenzylguanidine and $\left[{ }^{111} \mathrm{In}\right]$ octreotide uptake in benign and malignant pheochromocytomas. J Clin Endocrinol Metab. 2001;86:685-693.

9. Albérini JL, Meunier B, Denzler B, et al. Somatostatin receptor in breast cancer and axillary nodes: study with scintigraphy, histopathology and receptor autoradiography. Breast Cancer Res Treat. 2000;61:21-32.

10. Plöckinger U, Rindi G, Arnold R, et al. Guidelines for the diagnosis and treatment of neuroendocrine gastrointestinal tumours: a consensus statement on behalf of the European Neuroendocrine Tumour Society (ENETS). Neuroendocrinology. 2004;80:394-424.

11. Mayo KE, Miller LJ, Bataille D, et al. International Union of Pharmacology. XXXV. The glucagon receptor family. Pharmacol Rev. 2003;55:167-194.

12. Gotthardt M, Fischer M, Naeher I, et al. Use of the incretin hormone glucagonlike peptide-1 (GLP-1) for the detection of insulinomas: initial experimental results. Eur J Nucl Med Mol Imaging. 2002;29:597-606.

13. Wild D, Béhé M, Wicki A, et al. Preclinical evaluation of $\left[\operatorname{Lys}^{40}(\mathrm{Ahx}-\right.$ DTPA- $\left.{ }^{111} \mathrm{In}\right) \mathrm{NH}_{2}$ ] exendin-4, a very promising ligand for glucagon-like peptide-1 (GLP-1) receptor targeting. J Nucl Med. 2006;47:2025-2033.

14. Vertongen P, Ciccarelli E, Woussen-Colle MC, De Neef P, Robberecht P, Cauvin A. Pituitary adenylate cyclase-activating polypeptide receptors of types I and II and glucagon-like peptide-I receptors are expressed in the rat medullary carcinoma of the thyroid cell line 6/23. Endocrinology. 1994;135:1537-1542.

15. Beak SA, Small CJ, Ilovaiskaia I, et al. Glucagon-like peptide-1 (GLP-1) releases thyrotropin (TSH): characterization of binding sites for GLP-1 on alphaTSH cells. Endocrinology. 1996;137:4130-4138.

16. Crespel A, De Boisvilliers F, Gros L, Kervran A. Effects of glucagon and glucagon-like peptide-1-(7-36) amide on C cells from rat thyroid and medullary thyroid carcinoma CA-77 cell line. Endocrinology. 1996;137:3674-3680.

17. Perry T, Lahiri DK, Chen D, et al. A novel neurotrophic property of glucagonlike peptide 1: a promoter of nerve growth factor-mediated differentiation in PC12 cells. J Pharmacol Exp Ther. 2002;300:958-966.

18. Koehler JA, Drucker DJ. Activation of glucagon-like peptide-1 receptor signaling does not modify the growth or apoptosis of human pancreatic cancer cells. Diabetes. 2006;55:1369-1379. 
19. Wei Y, Mojsov S. Tissue-specific expression of the human receptor for glucagonlike peptide-I: brain, heart and pancreatic forms have the same deduced amino acid sequences. FEBS Lett. 1995;358:219-224.

20. Satoh F, Beak SA, Small CJ, et al. Characterization of human and rat glucagonlike peptide-1 receptors in the neurointermediate lobe: lack of coupling to either stimulation or inhibition of adenylyl cyclase. Endocrinology. 2000;141:13011309.

21. Vara E, Arias-Diaz J, Garcia C, Balibrea JL, Blazquez E. Glucagon-like peptide-1 (7-36) amide stimulates surfactant secretion in human type II pneumocytes. Am J Respir Crit Care Med. 2001;163:840-846.

22. Thorens B, Porret A, Buhler L, Deng SP, Morel P, Widmann C. Cloning and functional expression of the human islet GLP-1 receptor: demonstration that exendin-4 is an agonist and exendin-(9-39) an antagonist of the receptor. Diabetes. 1993;42:1678-1682.

23. MacNeil DJ, Occi JL, Hey PJ, Strader CD, Graziano MP. Cloning and expression of a human glucagon receptor. Biochem Biophys Res Commun. 1994;198: 328-334.

24. Munroe DG, Gupta AK, Kooshesh F, et al. Prototypic G protein-coupled receptor for the intestinotrophic factor glucagon-like peptide 2. Proc Natl Acad Sci US A. 1999;96:1569-1573.

25. Kieffer TJ, Habener JF. The glucagon-like peptides. Endocr Rev. 1999;20: 876-913.

26. Zhou J, Pineyro MA, Wang X, Doyle ME, Egan JM. Exendin-4 differentiation of a human pancreatic duct cell line into endocrine cells: involvement of PDX-1 and HNF3beta transcription factors. J Cell Physiol. 2002;192:304-314.

27. Meier JJ, Nauck MA. Glucagon-like peptide 1(GLP-1) in biology and pathology. Diabetes Metab Res Rev. 2005;21:91-117.

28. Hassan M, Eskilsson A, Nilsson C, et al. In vivo dynamic distribution of ${ }^{131} \mathrm{I}-$ glucagon-like peptide-1 (7-36) amide in the rat studied by gamma camera. Nucl Med Biol. 1999;26:413-420.

29. Stark A, Mentlein R. Somatostatin inhibits glucagon-like peptide-1-induced insulin secretion and proliferation of RINm5F insulinoma cells. Regul Pept. 2002;108:97-102.
30. Lamari Y, Boissard C, Moukhtar MS, Jullienne A, Rosselin G, Garel JM. Expression of glucagon-like peptide 1 receptor in a murine $\mathrm{C}$ cell line: regulation of calcitonin gene by glucagon-like peptide 1. FEBS Lett. 1996;393: $248-252$.

31. Buteau J, Foisy S, Joly E, Prentki M. Glucagon-like peptide 1 induces pancreatic beta-cell proliferation via transactivation of the epidermal growth factor receptor. Diabetes. 2003;52:124-132.

32. Hui H, Nourparvar A, Zhao X, Perfetti R. Glucagon-like peptide-1 inhibits apoptosis of insulin-secreting cells via a cyclic 5'-adenosine monophosphatedependent protein kinase A- and a phosphatidylinositol 3-kinase-dependent pathway. Endocrinology. 2003;144:1444-1455.

33. Huypens P, Ling Z, Pipeleers D, Schuit F. Glucagon receptors on human islet cells contribute to glucose competence of insulin release. Diabetologia. 2000; 43:1012-1019.

34. Byrne MM, McGregor GP, Barth P, Rothmund M, Goke B, Arnold R. Intestinal proliferation and delayed intestinal transit in a patient with a GLP-1-, GLP-2and PYY-producing neuroendocrine carcinoma. Digestion. 2001;63:61-68.

35. Tolessa T, Gutniak M, Holst JJ, Efendic S, Hellstrom PM. Glucagon-like peptide-1 retards gastric emptying and small bowel transit in the rat: effect mediated through central or enteric nervous mechanisms. Dig Dis Sci. 1998; 43:2284-2290.

36. Golpon HA, Puechner A, Welte T, Wichert PV, Feddersen CO. Vasorelaxant effect of glucagon-like peptide-(7-36)amide and amylin on the pulmonary circulation of the rat. Regul Pept. 2001;102:81-86.

37. Gutzwiller JP, Tschopp S, Bock A, et al. Glucagon-like peptide 1 induces natriuresis in healthy subjects and in insulin-resistant obese men. $J$ Clin Endocrinol Metab. 2004;89:3055-3061.

38. Raufman JP, Singh L, Singh G, Eng J. Truncated glucagon-like peptide-1 interacts with exendin receptors on dispersed acini from guinea pig pancreas: identification of a mammalian analogue of the reptilian peptide exendin-4. J Biol Chem. 1992;267:21432-21437.

39. Angelopoulos N, Dervenis C, Goula A, et al. Endocrine pancreatic insufficiency in chronic pancreatitis. Pancreatology. 2005;5:122-131. 